\title{
NBSIR 73-157
}

\section{National Program of Metrology for Ecuador}

T. M. Stabler

Office of Engineering and Information Processing Standards National Bureau of Standards

Washington, D. C. 20234

April 1973

Final Report

Prepared for

U. S. Aid Mission

to Ecuador

U. S. Department of State

Washington, D. C. 20523 



\section{NATIONAL PROGRAM OF METROLOGY FOR ECUADOR}

T. M. Stabler

Office of Engineering and

Information Processing Standards

National Bureau of Standards

Washington, D. C. 20234

April 1973

Final Report

Prepared for

U. S. Aid Mission

to Ecuador

U. S. Department of State

Washington, D. C. 20523

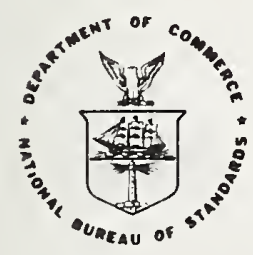

U. S. DEPARTMENT OF COMMERCE, Frederick B. Dent, Secretary 



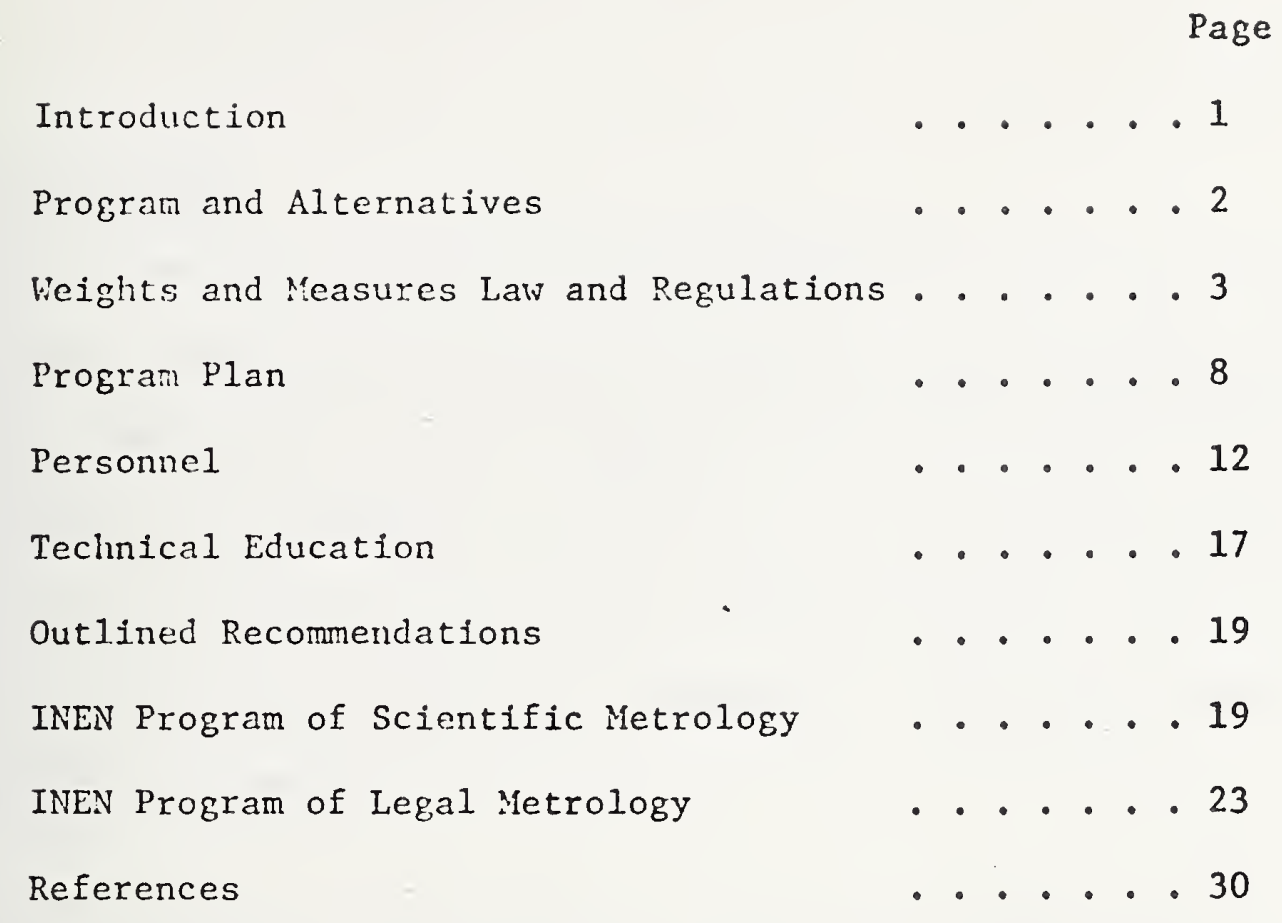





\section{Introduction}

The Ecuadorian Institute for Standardization (INEN) is a new organization, having been established in 1971 to promote the development of a centralized system of standards. Besides its basic function of preparing and publishing compulsory as well as voluntary standards relating to practices, processes, materials, products and commodities, INEN has the responsibility of developing a weights and measures program in Ecuador.

At the request of the Ecuadorian Institute for Standardization the United States Agency for Internatjonal Development (U.S. AID Mission, Quito) made arrangements for a weights and measures advisor from the National Bureau of Standards to visit Ecuador to assist in the development of a design for a metrological laboratory and a weights and measures law enforcement program including an inspection system, a training program, and other essentlal features. (Reference 1, NBS Report 10551.)

The National Bureau of Standards (NBS) representative, Thomas M. Stabler, visited Quito, Ecuador, in 1971, 1972, and 1973 to advise INEN and plan a possible approach to a program of scientific and legal metrology for Ecuador. 
The laboratory is now complete, the new standards installed and technical training in metrology was conducted by Harry Johnson of the NBS Office of heights and Measures (January 1973).

\section{PROGPAM AND ALTERNATIVES}

A program of weights and measures (legal metrology) for Ecuador must rest upon careful consideration by the appropriate government authorities of the objectives they want to achicve. This is the responsibility of the Ecuadorian government and a fully detailed program cannot be devised until objectives are firmly established. Recommendations can then be given. The program outlined here would provide the essential ingredients for the inftial stages such as the legal basis for regulations, reference (primary) National Standards, staffing and technical education.

In. the opinion of the Technical Director of INEN, the weights and measures activity should include a broad educational program for government, industry, and small businesses engaged in commerce. This should begin as soon as possible and continue to be a major effort. Accompanying this, effort could be a parallel program for educating the people and the workers to the importance and benefits of the program. Gradual public acceptance is expected despite the long history of traditional and foreign units employed in buying and selling, and the myriad of other factors affecting commerce such as transportation, communication, etc. 
Tradition, communication, and transportation impose barriers to a quick and easy solution to the weights and measures problems in commerce. Significant steps can be initiated now, however, that will provide a firm footing for gradual evolution of a nationwide uniform measurement system, which should employ the International System of Units (SI) officially recognized in world trade. Consideration should be given to the formation of a regional Conference on Weights and Measures, perhaps under the auspices of the Andean Pact, for the purpose of reaching agreement on uniform (Mode1) laws and regulations, performance specifications for standards, devices, packages, and administration of a weights and measures system on a South American or continental basis. Adoption of uniform laws and regulations should result in significant benefits to industries in the international market. Not only could this organization promote the Inftiation of uniform weights and measures programs for the benefit of participating nations, but it could also provide standards and certification for international trade broadly.

\section{WEIGITS AND MEASURES LAW AND REGULATIONS}

The proposed Weights and Measures Law of 1973 (Reference 2) establishes the authority for the weights and measures progran, defines the standards to be used, and outlines the responsibility of INEN, the Minister of Industry, Comnerce and Integration; commercial device omers, and users. The Regulations, which should include the specifications and tolerances 
for commercial devices, would have the force and effect of $1 \mathrm{aw}$, and support the basic statute by providing the guidelines and "rules" of enforcement.

The author has reviewed the proposed Law and believes it contains most of the necessary provisions for weights and measures supervision in Ecuador; however, a more general approach is recommended (See the Model State Law, Reference 3). The author suggests that the Fcuadorian offlcials consider including the following additional provisions in the law:

1. Authority for supervision and enforcement of the law by the national government only. Municipal responsibility may lead to non-uniform enforcement, duplication of effort and increased costs.

2. Authority to establish rules for packaging and to inspect packages for uniformity (Reference 4).

3. Authority to establish specifications, tolerances, and other technical requirements for commercial weighing and measuring devices (Reference 5).

4. Authority to set qualifications for weighmasters and to establish a register of qualified persons (Reference 6).

5. Authority to set qualifications for equipment service companies and to establish a register of qualifled firms (Reference 7). 
The proposed lieights and Measures Law provides for administration by the Minister of Industry, Commerce and Integration; defines the technical responsibilities of INEN and of the owners/users of commerical devices, establishes penalties for violations, and provides for the physical standards to be used in enforcement activities.

Regulations to implement the law should establish the basic requirement that commodities sold by weight shail be sold by net weight* rather than gross weight. ${ }^{* *}$ In addition, the law should assign specific authority to check packages for net contents. The U.S. Model State Packaging and Labeling Regulation (Reference 4) developed by the U.S. National Conference on Weights and Measures provides detailed requirements for packages including statement of net quantity of contents, name and address of packers, shippers, etc., (for domestic and Imported commodities). This model regulation should be examined to determine those features which are useful and adaytable to local conditions. This can only be done by an individual who is thoroughly familiar with the habits and mores of the Ecuadorian population.

The proposed law now provides for the establishment of a fee system and collection of fees by inspectors. Most countries have found this practice undesirable because of possible mishandiing of funds. An

\footnotetext{
*Net weight--the weight of a commodity excluding the carrier, container, package, or other wrapping material and inserts.

${ }^{* *}$ Gross weight--the weight of a commodity including the carrier, container, package and other wrapping material and inserts.
} 
alternate to this feature might be a licensing system with fees sent directly to INEN. Not only is the possibility for mishandling of funds greatly reduced, but enforcenent is enhanced by removing monetary considerations altogether (i.e., an inspector having to condemn a device and also to collect payment). Under one possible licensing plan, a device owner would submit the appropriate fee to INEN each year; in turn the Institute would send him a license for the current year irrespective of the number of inspections performed or whether devices were approved or rejected. The U.S. Model State Weights and Measures Law could serve as a reference for the proposed revision of the proposed statute.

Usually, a fee system cannot provide adequate financing for the total operation of weights and measures programs; consequently, government support will be required. Most countries consider that weights and measures programs are sufficiently in the public interest to justify such public support.

Regulations relating to requirements for devices and packages should be adopted by actions apart from the weights and measures law, because of the need for periodic revisions of regulations. The appropriate regulations can be referred to in the law. The various model laws and regulations listed in this report as references may be useful when drafting Ecuadorian practices. These models not only set forth performance specifications but also standards of practices and procedures which are equally important. 
Another essential ingredient of the program is the physical standards of weights and measures now housed at the INEN Metrology Laboratory. National Reference (Primary) Standards and working or secondary standards (comparable to field standards used by the states in the U.S.) are necessary for enforcement of legal requirements. The primary standards of mass, length, and volume are presently housed in the INEN Metrology Laboratory and serve as the National Standards for Ecuador." Commercial measurements and legal determinations should be traceable to the National Standards. Primary reference standards are essential to provide the basis for an equitable level of accuracy in commerce. To provide traceability and the link between commercial measurements and the national Standard, adequate field standards of weights and measure are employed; these include standard weights, capacity measures, and linear standards. The standards program may be broadened in the future to include electrical standards, temperature standards, gage blocks and other measuring instruments; however, the Infial requirements usually relate to the measurement of mass, length, and volume. Calibration of field standards against national standards does not necessarily ensure that measurements are accurate since other aspects of the measurement process may not be under adequate control. As measurement practices in the commerce of Ecuador become more

\footnotetext{
* (The National Standards should be compared at regular intervals-approximately 10 years--with standards of the United States, Great Britain, France, West Germany, or other major industrial nations to assure accuracy.)
} 
sophisticated, attention will have to be given to the entire measurement procedure in order to be sure that systematic errors are minimized.

An environmentally controlled laboratory has been provided to house the National Standards and laboratory instruments. An area of approximately $300 \mathrm{~m}^{2}$ usually is adequate in the initial stages of a metrology program. State weights and measures laboratories in the U.S. have found that a ground floor location with temperature controlled to $\pm 2.0^{\circ} \mathrm{C}$ (within commercial air conditioning capability) and relative humidity of less than $50 \%$ are adequate for calibrations and tests which are needed. The effect of vibration of the laboratory is an important consideration. The Institute should provide the necessary controls for a dust free, temperature and humidity controlled environment. Indeed, unless strict precautions are taken, present equipment already on hand may be subject to damage by corrosion and dust.

\section{PROGRAM PLAN}

The first step in the implementation of the program is the enactment of a Law. The Law provides the legal basis for the National Reference Standards which are now established at the INEN Metrology Laboratory. Working or field standards should now be certified by the laboratory to establish traceability of accuracy. These field standards are used in the testing of commerical weights and measures. 


\section{Special Considerations}

Before discussing essential elements in detail, the situation in Ecuador should be reviewed. Policy of the national government and INEN will, in large part, deternine the degree of success of this program. The national government is probably the largest single user, purchaser, and consumer of products either weighed or measured. An effective weights and measures program to assure reliable quantity determinations in commerce could result in important governmental savings; in the purchase of agricultural products, manufactured goods, petroleum, etc. Government requirements (contracts) should include the use of approved scales and meters and support a package control program. Contracts with suppliers could require traceability to the National Standards.

The National Metrology Laboratory and standards program rank as high priorities since they are essential in the establishment of foundation for measurement. With this initial phase completed, the inspection of commercial weights and measures can now commence (i.e., testing of scales, meters, packages).

Another aspect of the weights and measures program should be the survelllance of government weighing and measuring devices at import stations. These devices should be operated by qualified weighmasters or government officials trained in the operation of weighing equipment 
after examination and certification by INEN government support of the weights and measures program is essential if the inspection program is to provide the necessary equity.

Ecuadorian authorities are determined that consumers receive fair value in the market place. A measurement program for industrial products could result in immediate increase in confidence by the consuming public, industry, and the government. Liquid flow metering is an illustration of a readily applicable technology that can be adopted to ensure equity. Flow metering devices have been standardized to a high degree by the petroleum industry, and there usually exists in the industry an effective service program for the repair and maintenance of gasoline pumps, truck-mounted meters, and high-capacity meters found on aircraft and ship fueling devices.

An effective way to administer the weights and measures program may be to establish regional or provincial weights and measures offices to communicate with commerce, industry, farmers, and agencies of the government in the designated areas. The activities of the provincial weights and measures offices would be coordinated with the principal government administrator, INEN, and other agencies providing assistance (U.S. AID, etc.). 
Economic advice on agricultural marketing practices is beyond the scope of this report, but the author wishes to caution the recipients of this report that a weights and measures program, no matter how effective, is only one important factor in a marketing system. Other factors include price structure, information accessibility, transportation facilities, storage capability, weighing accuracy, etc., and these factors all relate to other segments within the same industry. Approach

The following sequence, in order of priority, is suggested as an approach to the development of a weights and measures program for Ecuador:

1. Enact up-dated version of the Weights and Measures Law.

2. Train highest level administrative staff in laboratory metrology and weights and measures administration. (An appropriate six-month training program could be provided by NBS.)

3. Provide calibration and testing program (mass, length, volume) for industries (agricultural, manufacturing, chemical, etc.), and universities.

4. Develop government-wide policies and procedures to insure that government procurement is in accordance with weights and measures regulations.

5. Initiate field inspection program within the manufacturing and petroleum industries.

6. Develop weights and measures program within the framework of the agricultural sector (coffee, grain, animal, etc.). 
As a follow-up to the installation of new standards in the state laboratories, the U.S. National Bureau of Standards conducts a Laboratory Auditing Program (LAP) in which 35 states participate, and which provides the state personnel a program of continuing professional development, surveillance of standards and instruments, self-evaluation, and NBS certification of traceability. The feasibility of foreign laboratory participation is being considered.

\section{PERSONNEL}

The weights and measures program is only one function of INEN and the National Government. It would be difficult for the Technical Director of INEN to supervise all operational details of this and other areas of his responsibility; consequently, a program administrator might be required to devote full time to this project.

In addition to the Technical Director of INEN and the Minister of Industry, Commerce and Integration and clerical employees, the weights and measures staff should consist of a weights and measures program administrator, field supervisors, inspectors, a metrologist and laboratory technician. The staff structure and responsibilities listed below are considered appropriate for carrying out the calibration and testing program specified in the proposed law and regulations. The number of field personnel will be dependent upon detailed national objectives to be set by Ecuadorian authorities. 


\section{ADMINISTRATOR}

The program Administrator should be responsible for national enforcement of the weights and measures law and regulations. He should implement the policies and programs for weights and measures. The Administrator supervises hiring of new personnel, training of inspectors and metrologists, procurement of necessary equipment, and allocation of personnel and equipment for optimum efficiency. Important aspects of his responsibility which deserve emphasis are public relations and education, and he should expend a significant portion of his effort in these areas.

Effective communication with INEN and the National Government 1s essential. The Administrator should keep them apprised of program progress and of requirements and difficulties that bear on matters relating to broad objectives and policies. He should spend considerable time in thinking and planning for the growth of the program.

Qualifications for the position of Administrator should include a university degree in science or engineering and experience in management of organizations and personnel development. He should have had specialized training in the administration of a weights and measures program, preferably both domestic and abroad. 
2. SUPERVISOR

The Supervisor's primary responsibility is to coordinate the weights and measures fleld inspection program. He assists in the scheduling of inspections and tests and provides technical expertise in training of field personnel, in the conduct of special investigations, and in troubleshooting of problems when they occur. The Supervisor has direct supervision of the inspectors to assure that the law and regulations are being enforced in an equitable manner and that established policies and procedures are being adhered to.

Problems of interpretation and application of the law and regulations, and disputes arising from misunderstandings and lack of information should all come to the attention of the Supervisor for mediation.

An important responsibility of the Supervisor is to evaluate the field personnel and their effectiveness in performing their duties. Close surveillance of performance can provide a measure of training needs, as well as the level of capability and responsibility that can be expected of the individual inspectors. 
Intially, the weights and measures program should include one field supervisor, but as the program grows, additional supervisors may be needed to effectively coordinate inspection activities. At a later date supervisors might be assigned to regional offices close to their areas of responsibility, perhaps to a provincial or regional office.

\section{INSPECTOR}

The Inspector, under the direction of the Supervisor, inspects and tests weighing and measuring devices and packages to determine their conformity to the law and regulations.

Qualifications for this position should include high school education, mechanical ability preferably with experience in tasks requiring similar manual dexterity, and a high standard of moral character.

In the conduct of his duties, an inspector may be subjected to temptations which, though not illegal, may subject him to accusations of improper influence. The Inspector must apply equitably the legal codes of weights and measures using mature judgment in complex cases where obvious solutions are not evident. In reaching his decisions, he must never compromise the moral codes for honesty. If he does, he becomes ineffective and should not be permitted to continue in his position of public trust. 
The Inspector's image as a trusted public servant must be supported by a high level of technical competence. A thorough knowledge of the law and regulations should be balanced by an understanding of the basic principles of weighing and measuring and the devices employed therein.

An on-going technical training program should be devised to continue the professional development of the Inspector. Training should begin with an in-depth study of the laws and regulations, and the fundamental considerations of weights and measures law enforcement. INEN policies and procedures should be reviewed. New inspectors should be trained in the field under the supervision of an experienced inspector and field supervisor. The new Inspector should not be permitted to function independentiy until the Supervisor believes he has an adequate background to perform his duties in an acceptable manner.

\section{METROLOGIST}

The laboratory provides measurement services for the universities, technical colleges, and industry. Professional consultation in measurement science could be a most important service to industry in its quantity and quality control programs--that is, how to accurately measure raw materials purchased and finished goods produced. 
The Metrologist operates the laboratory program and conducts tests and calibrations of weights and measures standards. He maintains calibration of the National Standards and traceability of field standards to assure that legal requirements for accuracy are met.

The metrologist should participate in training programs that cover care and maintenance of standards and laboratory Instruments, techniques and procedures in testing and calibrating physical standards, data collection and reporting, and administration of a metrology laboratory. Many of the tasks in the laboratory will be routine in nature and can be handled by a technician. In the event that the Metrologist is re-assigned, it will be advantageous to have a qualified person or persons ready to fill in and keep the program in operation.

\section{TECHNICAL EDUCATION}

A well balanced technical ecucation program is necessary for the foreseeable future and is needed at all levels.

Since practical experience and application are essential to the effective supervision of the metrology laboratory and program of enforcement of the Ecuadorian Weights and Measures Law, it is recomended that an engineer of the INEN staff (preferably the indivudual who will uitimately serve as Weights and Measures Administrator), participate in an intensive 
trajning program. Such a program, of six months duration, can be provided by the National Bureau of Standards. This training will provide the necessary technical background to qualify the INEN representative as an instructor to train other Ecuadorian officials in testing and calibration procedures relating to laboratory and field applications. The training program should include:

1. Metrology Laboratory design, including environmental controls and equipment.

2. Basic Metrology--care and maintenance of standards, calibration techniques, laboratory procedures, administration.

3. Intermediate Metrology--collection of surveillance data, monitoring standards and instruments, laboratory evaluation, statistical analysis.

4. Weights and measures administration and supervision, resource allocation, inspections, tests, reporting, evaluations.

5. Writing of specifications, tolerances and other technical requirements for commercial weighing and measuring devices.

6. Package control--requirements for packages, labels, test procedures.

7. Field training with state weights and measures officials. Inspections and tests of commercial devices and packages.

8. Weights and measures administration at a state office, reports, official actions, and progran evaluation.

A comprehensive training program should consist of the above but should not necessarily be limited to the items 1isted. Technical education should be tailored to the specific needs of the individual and the program he will administer. 


\section{OUTLIALD RECORTIENDATIONS}

INEN Program of Scientific Metrology

The program of Scientific Metrology at INEN should include the ten considerations listed below. They are presented in the general order of priority; however, it may be necessary to alter the list and add items not considered here as the program evolves.

1. Technical Training for the Metrologist. NBS conducts training for State laboratory metrologists In Basic, Intermediate, and Advanced Metrology. The complete course consists of approximately 200 hours in calibrations, tests, administration, care and maintenance of standards and instruments, laboratory techniques and procedures. It is recommended that the feasibility of NBS technical training for the Metrologist be investigated.

2. Internal Data Control.

INEN policy and a practical system for laboratory data control should be established. It is important to decide upon a systeln for data collection, documentation, filing, and reporting. Redundance is required to minimize errors and to build confidence in the system.

3. INEN Calibrations and Tests.

Uniform and appropriate language must be established for Reports of Calibration, Reports of Test, Certificates, and letters of verification or laboratory approval. Specifications 
for standards should be adopted (References 8, 9, 10: NBS H-105-1, 105-2, 105-3). A fee schedule should be established.

4. Administrative Policy.

For reasons of security and care of the standards and precision instruments, access to the new Metrology Laboratory should be restricted to the Director and Metrologist. No one other than trained personnel should handle the standards or operate the instruments. The laboratory doors should remain locked at all times. Control of the Laboratory environment should be considered of highest priority. Instruments and standards can be easily damaged by untrained persons and can deteriorate through unclean conditions, dust, high humidity, etc.

5. Maintenance of Standards and Instruments. Regular maintenance of balances should be considered. Annual or bi-annual servicing by a qualified person (Voland or Mettler) should provide long term, troublefree operation of these precision instruments. The Metrologist should regularly clean and service all other standards and laboratory equipment.

6. Annual Reporting.

The form for the annual weights and measures report should be based upon the requirements of government for information and the system of reporting that will provide 
the most meaningful, relevant information. For example, information may be requested relative to the economic impact of tests and calibrations upon industry and commerce, cost vs. benefits, economic advantages for the export market, etc.; in addition, listing of laboratory customers and description of standards calibrated.

7. Short Term Program.

The INEN Program of Scientific Metrology should be discussed and established in terms of activities for the next one to two years. An ad hoc advisory committee consisting of representatives from industry, universities, and government could provide valuable assistance in the early stages of laboratory services to these institutions, and help identify possible pit falls, future customers, and proper direction for growth. In the first year or two it is important to establish a limited calibration and testing program held we11 within the capability of the Metrology Laboratory. Although an effective public relations effort can be beneficial to the new program, "over-selling" of available services may create administrative and other problems such as a backlog of requests for testing, for professional consultation, public appearances, etc. Laboratory services should be scheduled in advance and commitments made within the capability of the avallable personnel, 
time and budget. INEN should prepare pamphlets, and other material to be used in announcing available laboratory services.

8. Long Term Program.

Planning for the long term should include program growth for the period extending to 10 years. Goals should be well-defined and a permanent advisory committee appointed to deal with the requirements of the Metrology Laboratory program during this interval of time. Budget requirements for program expansion, personne1, new standards and equipment, and technical seminars should be considered by the advisory committee.

9. Technical Training.

Perhaps technical training, and education in a broader sense, will constitute the most important program of the INEN Metrology Laboratory; at least in terms of long range objectives. The "how, when, and why" of measurement accuracy and precision should be included in any educational program as they are of paramount importance in the transfer of measurements from one standard to another and from one laboratory to another. (Measurements can be meaningless without proper controls for procedures, environment, application, and understanding.) A broad program of technical education and training is necessary for industry, universities, government, commerce, and weights and measures officials. 
10. Laboratory Auditing Frogram.

The INEN program of Scientific Metrology might include certification of other laboratories. Such a program should include "round robin" testing of standards, an educational program, a laboratory evaluation or auditing program (i.e., NBS Laboratory Auditing Program), and possible cooperation with laboratories of other Andean Pact nations.

B. INEN Program of Legal Metrology

The future program of Legal Metrology for Ecuador will be based upon the authority established by the proposed new Law of Weights and Measures. When the law is signed by the President, it will set forth certain responsibilities for INEN including maintenance of the national standards, system of units (SI), certification of standards and weights and measures used in the testing of commercial devices. The Minister of Industry, Commerce and Integration will be given principal responsibility foe enforcement. The Law provides for conversion to the Metric (SI) System of Units through a 10 year program.

There are two considerations relative to the proposed Weights and Measures Law in its present form. First, it could be more general and less detailed. Regulations having the force and effect of law could provide the details, specifications, and other requirements to support the law in its basic context. Second, the Law provides for a National and municipal (cities) program of enforcement. This may result in duplication of effort, nonuniformity, and added expense. For a uniformly administered, 
effective, and equitable program of weights and measures in Ecuador, a single National Program is recomended. There should be one government office with total responsibility. This should result in reduced costs and a higher level of efficiency.

The following recommendations are listed in order of priority; however, the list may be altered to provide for additional items:

1. Weights and Measures Law.

In addition to the above, the Law should provide for

a. licensing of weighmasters;

b. licensing of servicemen (for repair of commercial devices);

c. checking of packages; and

d. unit pricing of random size (weight, etc.) packages.

2. Regulations. Regulations should include:

a. Specifications and Tolerances for Commercial devices (instruments).

b. Packaging and Labeling.

c. Package sizes and standards of fill.

d. Method of Sale of Commodities (Reference 11).

e. Requirements for Unit Pricing (Reference 12).

3. Nationwide Survey.

The plan for administration of the Weights and Measures

Law should be preceeded by a nation-wide survey to

Identify the problem areas in commercial measurement

and to establish a rational base for the future

program. In addition, the survey will focus immediate 
attention to the scope of the task at hand: to develop within the national government an equitable program of weights and measures that will furnish the level of confidence in the market place that the law intends. The survey should include testing of commercial devices and packages in the major markets of Ecuador. Principal industrial products should be tested also. The economic importance of this program to the nation and various segments of the economy can then be evaluated--based upon the results of the survey.

4. Program of Law Enforcement.

The program of law enforcement should be based upon the concept that the packager or device owner/operator is responsitle for accurate measurement. When violations of the Law and Regulations are discovered, he is held responsible. Consequently, servicemen and repairmen are responsible for their maintenance programs, and weighmasters are responsible for their weights. A packer must deliver the correct net weight.

To analyze the effectiveness of the weights and measures program, a selective sampling procedure may be used. It should be based upon:

a. economic importance of the device or commodity in money value. 
b. compliance level, and past history of compliance.

Program emphasis is placed upon the areas of commerce and industry of greatest economic importance and which demonstrate serious measurement problems (non-compliance, short weight or measure). Cost/benefit analysis, EDP, operations research, are useful techniques in the management of a weights and measures program.

5. Technical Training.

A program for the technical training of wetghts and measures officials, industry representatives, and service personnel is of major importance. They must receive training in the areas of enforcement that relate to their Interests; i.e., scale testing, meter testing, package control, law, regulations, etc. The more effective the training program, the more effective will become the enforcement program. INEN will probably shoulder the primary responsibility for a technical training program which should consist of instruction in administration for program managers, supervision for field supervisors, and inspections and tests for the field inspectors.

6. Pattern Approval.

This provision in the law, sometimes called "type approval," is necessary as it controls the importation, 
manufacture, and commercial use, of devices, packages, and labels of inferior performance and design. INEN plans to conduct an engineering evaluation of devices, packages, and labels before they are used in commerce thus prohibiting unfair competition from illegal weights and measures.

7. Calibrations and Tests.

INEN will be responsible for the testing and certification of field standards and equipment used in the weights and measures service. All field standards should be tested at least annually, or more often if necessary, and be certified for their use in the control of packages and commercial devices.

8. Metric Conversion.

The Law provides for a National Advisory Board for planning metric conversion. INEN should provide technical information to this body, industry, and commerce concerning metric standards, instruments, commercial devices and packages. Educational programs should be designed for the general public and audio-visual aids (motion pictures, pamphlets, etc.) prepared for wide distribution. Also, speeches, informal presentations, and seminars will aid the nationwide program of metric education.

The Metric Board should obtain voluntary conversion schedules from industry based upon the economic factors 
(time, costs, etc.) involved and plan for a metric industry and commerce within the ten years as established by the law. However, there likely exist certain elements in Ecuador's economy and future measurement system that probably should remain in the customary or traditional units, to which no benefit would be derived from conversion, or for which costs of conversion would be prohibitive, or simply would be impractical. These areas should be identified.

One of the most important considerations is the conversion to the metric system by commerce. Commercial devices (packages, scales, meters, weights and measures, etc.) should be placed on a mandatory schedule for conversion to metric units. Packers and manufacturers can assist in the determination of reasonable schedules for individual classes of products and commodities. Many factors will have to be considered such as the avallability of metric instruments and spare parts, the expected life span of present equipment, inventory of packaging material and labels, etc. However, deadlines should be established for the change to metric units in commerce and these should be enforced. Competition between manufacturers and packers, for the export/import and domestic markets, may force the 
creation of a mandatory plan if one is not established in the beginning of the program.

9. Andean General Conference on Standardization.

It may be feasible to conduct an Andean Conference to discuss and adopt model laws and model regulations for weights and measures. These would include performance and design specifications for commercial weighing and measuring devices, and for packaging and labeling. Certainly, it will benefit all nations of the Andean Pact to subscribe to uniform laws and regulations for weights and measures. This is a basic requirement for international trade. Industrial standards (ISO, IEC, etc.) are equally important and should also be considered for adoption by the member nations. 


\section{References}

1. NBS Report 10551, Program of Legal ifetrology and Scientific Metrology, Quito, Ecuador (1971).

2. Weights and Measures Law-La Siguiente Ley De Pesas Y Medidas, Quito, Ecuador (1973).

3. Model State lieights and Measures Law (1971).

4. Model State Packaging and Labeling Regulation (1972).

5. NES Handbook 44, Specifications, Tolerances and Other Technical Requirements for Commercial Vleighing and Measuring Devices (1972).

6. Model State Weighmaster Law.

7. Model State Registration of Servicemen and Service Company Regulation (1966).

8. NES Handbook 105-1, Specifications and Tolerances for Fie1d Standard Weights (1972).

9. NBS Handbook 105-2, Specifications and Tolerances for Field Standard Measuring Flasks (1971).

10. NBS Handbook 105-3, Specifications and Tolerances for Metal Volumetric Field Standards (1971).

11. Model State Method of Sale of Commodities Regulation (1972). 12. Model State Unit Pricing Pegulation (1972).

Copies of References were sent with copies of the oriêinal report to the Agency for. International Development (U.S. A.ID Mission, Quito). Additional copies are available from the National Eureau of Standards, Office of Engineering and Information Processing Standards, Washington, D.C. 20234. 


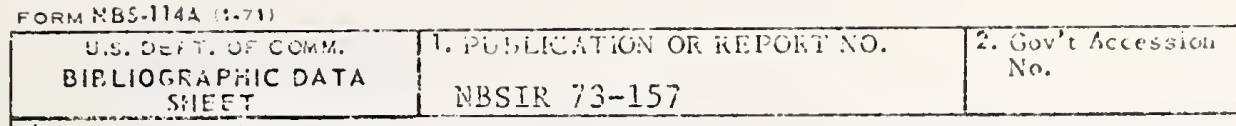

4. TITIL AND SUETITLE

Nations 1 Program of Metrologs for Ecuador

7. AUTHOR(S)

Thomas M. Stabler

9. PERFORMING ORG.INIZATION NAME AND ADDRESS

NATIONAL BUREAU OF STANDARDS

DEPARTMENT OF COMMERCE

WASHINGTON, D.C. $20 \angle 344$

12. Sponsoring Organization Name and Iddress

Same as Item 9.

15. SUPPLEMFNTARY NOTES

16. ABSTRACT (A 200-word or less factual summary of most significant information. If document includes a siznificant bibiliography or litcrature survey, mention it here.)

At the request of the Ecuadorian Institute of Standardization (INEN) the U.S. AID made arrangenents for a weights and measures advisor to assist in the development of a prograr for scientific and legal metrology, including the design of a metrology laboratory, inspection system, a training progran, anc other essential features. A four week survey by an WBS representative has resulted in recormendations for a metrology laboratory, physical standards, and Eckadorian weights anc measures lew, regulations, and control program.

Considered also were the Ecuadoxian National Standards of mass, length, and volume; precision balances, and other laboratory instruments. A program of technical education was recommended for an INEN engineer (Program Administrator) and for other members of the INEN laboratory staff.

17. KEY WORDS (Alphabetical order, separaced by semiculons) calibration and testing; Ecuadorian Institute of Standardization (INEN); field inspections; mass, length, anc volume standards; metrolocy laboratory, model law and regulations; technical education; U.S. AID

18. AVAILABILITY STATEMENT

[X] UNI.IMITED.

FOR OIFICIAL DISTRIBUTION. DO NOT RELEASE TO NTIS.

\begin{tabular}{|l|c|}
$\begin{array}{c}\text { 19. SECURITY CLASS } \\
\text { (TIIS REPORT) } \\
\text { UNCL. ASSIFIED }\end{array}$ & 33 \\
\hline $\begin{array}{c}\text { 20. SECURITY CLASS } \\
\text { (TIIIS PAGE) } \\
\text { UNCL ASSIFIED }\end{array}$ & 22. PriCe \\
\hline
\end{tabular}


